\title{
THICKNESS DETERMINATION OF CORROSION LAYERS ON IRON USING XPS DEPTH PROFILING
}

\author{
DOLOČEVANJE DEBELINE KOROZIJSKIH PLASTI NA ŽELEZU Z \\ UPORABO XPS GLOBINSKEGA PROFILIRANJA
}

\author{
Lukáš Kalina, Vlastimil Bílek Jr., Marek Bušo, Jan Koplík, Jiří Másilko \\ Brno University of Technology, Faculty of Chemistry, Materials Research Centre, Purkyňova 118, 61200 Brno, Czech Republic \\ kalina@fch.vutbr.cz \\ Prejem rokopisa - received: 2016-07-15; sprejem za objavo - accepted for publication: 2018-03-08
}

doi:10.17222/mit.2016.180

\begin{abstract}
The study deals with the methodology and thickness determination of the corrosion layers of ferritic steel samples using X-ray photoelectron spectroscopy (XPS) equipped with the ion-gun source system enabling destructive depth profiling. It is well known that XPS is one of the most often used techniques for determining both the thickness and chemical composition of passive films or corrosive layers. Unfortunately, the thickness of ion-gun-etched layers can only be estimated for simple samples and standards. Corrosion layers are heterogeneous and vary in composition; therefore, the etching rate is specific for each corrosion layer. The results of this work provide the possibility for a fast and easy determination of the ion-gun sputtering effect with exact settings for multi-compound chemical structures. The knowledge related to the thickness of corrosion or passivation layers would help greatly in their characterization.

Keywords: X-ray photo-electron spectroscopy, ion gun, depth profiling, corrosion layer
\end{abstract}

Študija opisuje metodologijo in določevanje debeline korozijskih plasti na vzorcih feritnega jekla z uporabo rentgenske fotoelektronske spektroskopije (XPS; angl.: X-ray Photoelectron Spectroscopy). Uporabljena naprava je bila opremljena z ionsko puško, ki omogoča destruktivno globinsko profiliranje. Znano je, da je XPS ena od najbolj uporabljanih tehnik za določevanje tako debeline kot tudi kemijske sestave pasivacijskih filmov ali korozijskih plasti. Žal se debelina plasti, jedkane z ionsko puško, lahko oceni samo na enostavnih vzorcih in standardih. Korozijske plasti so heterogene in imajo spremenljivo kemijsko sestavo, zato je hitrost jedkanja specifična za vsako korozijsko plast posebej. Rezultati tega dela zagotavljajo možnost hitrega in enostavnega določevanja učinkov jedkanja z ionsko puško z natančnimi nastavitvami za večkomponentne kemijske strukture. Znanje, pridobljeno v okviru tega dela, bo lahko v precejšnjo pomoč pri karakterizaciji debeline korozijskih ali pasivacijskih plasti.

Ključne besede: rentgenska fotoelektronska spektroskopija, ionska puška, globinsko profiliranje, korozijska plast

\section{INTRODUCTION}

X-ray photoelectron spectroscopy (XPS), often referred to as electron spectroscopy for chemical analysis (ESCA), is a surface analytical technique that has matured into an essential tool for the characterization of many materials. The ability to obtain the information on the surface-element composition as well as on the chemical state and electronic state of the elements that exist within a material is one of its advantages.

XPS of course owes its quantification to Einstein's explanation of photoelectric effect in $1905 .{ }^{1}$ In the period since the late 1950s, the photoelectric effect has been developed into one of the most powerful tools for the study of the composition of the matter. ${ }^{2}$ Kai Siegbahn took the advantage of this fact for the development of high-resolution XPS, for which he received the Nobel Prize in 1981. Modern XPS spectrometers depend largely upon monochromated $\mathrm{Al} \mathrm{X}$-rays as a primary excitation source to eject a photoelectron from an atom at the sample's surface (from the top $1 \mathrm{~nm}$ to $10 \mathrm{~nm}$ ). ${ }^{3}$ Photoelectrons emitted from a sample are separated on the basis of their kinetic energy and analyzed in an XPS detector by measuring the kinetic energy of electrons which provides the information needed for determining the elements present in the sample.

In a research of thin corrosion or passivation layers, it becomes necessary to know the chemical composition of these layers as well as their thickness. ${ }^{4}$ Especially the knowledge about the oxidation or corrosion behavior of iron provides important information related to the utilization of protective passive films on its surface or the magnetic properties. Therefore, the understanding of the corrosion processes of iron is important when choosing the material for a certain purpose. The composition of the corrosion layers is most reliably determined with $\mathrm{X}$-ray diffraction. However, in many cases the oxide film is too thin for this technique to be applied and the identification of the phases requires sensitive surface chemical methods. For this purpose, the routine part of analyzing the surface and thin film for compositional depth profiling is the use of a combination of XPS and ion-gun etching. The ion beam is obtained due to the collision between gas and electrons; the solid surface is then bombarded with energetic argon ions to successively remove the outermost layers and the underlying layers become a new surface. This process reveals a new layer, 


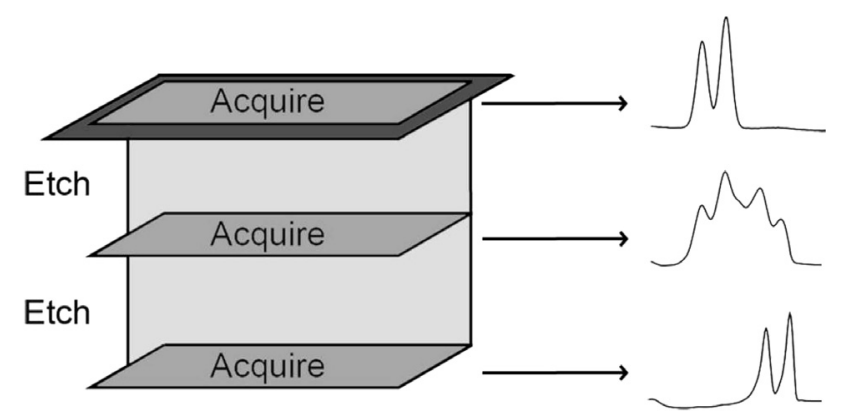

Figure 1: Process of XPS depth profiling

which is then characterized with XPS (Figure 1). It would be also very useful to determine the sputter effect of the ion gun to find the depth of etching at a specific voltage and the spot size for chemical compounds or more complex systems. In this paper, a detailed XPS analysis of the corrosion layers on steel samples and the methodology for determining their thickness are presented.

\section{EXPERIMENTAL PART}

\subsection{Materials and sample preparation}

Ferritic steel was used as the base material for the test samples. The steel was cut to the required dimensions of $(10 \times 15 \times 1) \mathrm{mm}$ using a Struers Secoton-50 saw. Small specimens were grinded and polished and then exposed to the corrosion environment in a furnace under normal atmospheric pressure, with various exposure times and temperature conditions $(100,200,250$ and 600$){ }^{\circ} \mathrm{C}$. The samples were then immediately loaded into the XPS system with an ultra-high vacuum.

\subsection{Ion-gun etching}

The depth profile was acquired by $\mathrm{Ar}^{+}$etching. The ion gun was under full computer control allowing the standard settings to be recorded and recalled for future experiments. The standard operating conditions for the depth profile were a beam energy of $4 \mathrm{keV}$ and a sputter current of $2.6 \mu \mathrm{A}$. The ion beam was scanned in a square raster $\left(4 \mathrm{~mm}^{2}\right)$ over the specimen surface. The size of the raster was approximately 10 times larger than the XPS-measured area. Rastering the ion beam in this way ensures that the XPS spectra are representative in the middle of the square etch pit and not at the edge where the ion beam may have caused uneven etching ('edge' effects).

\section{$2.3 X$-ray photoelectron spectroscopy (XPS)}

XPS analyses were carried out with an Axis Ultra DLD spectrometer using a monochromatic Al $\mathrm{K} \alpha$ $(h v=1486.7 \mathrm{eV}) \mathrm{X}$-ray source operating at $150 \mathrm{~W}$ $(10 \mathrm{~mA}, 15 \mathrm{kV})$. The spectra were obtained using an analysis area of $\sim 300 \times 700 \mu \mathrm{m}$. The Kratos charge neu- tralizer system was used for all the analyses. High-resolution spectra were measured with a step size of $0.1 \mathrm{eV}$ and pass energy of $20 \mathrm{eV}$. The instrument base pressure during the measurements was consistently $2 \cdot 10^{-8} \mathrm{~Pa}$. The spectra were analyzed using the CasaXPS software (version 2.3.15) and were charge-corrected to the main line of the $\mathrm{C} 1 \mathrm{~s}$ spectral component $(\mathrm{C}-\mathrm{C}, \mathrm{C}-\mathrm{H})$ set to $284.80 \mathrm{eV}$. The standard Shirley background was used for all the sample spectra.

\section{RESULTS AND DISCUSSION}

Four various temperatures were chosen for the study of the corrosion rate at different exposure times. At the temperatures ranging from $150{ }^{\circ} \mathrm{C}$ to $600{ }^{\circ} \mathrm{C}$, ferritic steel reacts chemically with oxygen from the air/aerial oxygen to form a surface film with various kinds of iron oxides. This type of corrosion involves a high-temperature oxidation reaction, which occurs in the dry state. The formation of iron oxides on steel samples usually follows a logarithmic rate, which can be observed in Figure 2. The character of the corrosion layer depends mainly on the applied temperature. It can be expected that samples heated at a temperature below $600{ }^{\circ} \mathrm{C}$ will be covered with $\mathrm{Fe}_{3} \mathrm{O}_{4}$ and $\mathrm{Fe}_{2} \mathrm{O}_{3}$ and above this temperature, samples oxidize to form $\mathrm{FeO}, \mathrm{Fe}_{3} \mathrm{O}_{4}$ and $\mathrm{Fe}_{2} \mathrm{O}_{3}$. Similar results were also obtained during the XPS depth profiling (Figure 3) of the sample exposed to the temperature of $600{ }^{\circ} \mathrm{C}$ for $24 \mathrm{~h}$. The investigation of the XPS spectra was carried out theoretically. The Gupta and Sen (GS) peak parameters relate to the multiplet splitting of unpaired photoelectrons in the valence band and arise from different spin distributions of electrons of the band structure. ${ }^{5-6}$ The $\mathrm{Fe} 2 \mathrm{p}_{3 / 2}$ envelopes from high-spin $\mathrm{Fe}^{3+}$ compounds follow the GS predictions very well even when the system contains different iron oxides and becomes complicated due to spectral overlaps. Based on these fitting parameters, it was determined that the sur-

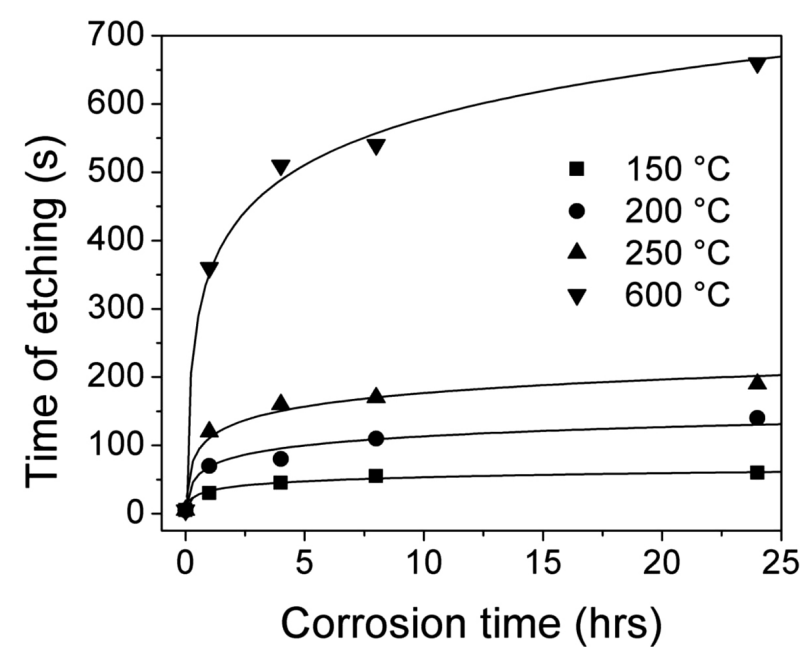

Figure 2: Dependence of the ion-etching time on different high-temperature corrosion exposures 
face of the sample was formed by $\alpha-\mathrm{Fe}_{2} \mathrm{O}_{3}$ with a very thin $\alpha$-FeOOH phase (Figure 3A). After the etching away of several nanometers, another corrosion product appeared (Figure 3B). This spectrum is distinct from the previous one, with a shoulder on the low binding energy side that is specific to the presence of the $\mathrm{Fe}^{2+}$ multiplet component in the $\mathrm{FeO} \cdot \mathrm{Fe}_{2} \mathrm{O}_{3}$ phase. The extension and the shift of the shake-up satellite peak, related to the interaction of the outgoing photoelectron with a valence electron, is also an additional effect pertaining to the $\mathrm{Fe}^{2+}$ portion. Finally, after $510 \mathrm{~s}$ of ion etching (Figure 3C), an asymmetric peak of iron was detected. With respect to the roughness of the sample, ion etching was stopped when the amount of $\mathrm{Fe}^{0}$ was equal to that of iron oxides.

The determination of the thickness of a corrosion layer is dependent on the sputter yield of each phase present in the system. This physical constant describes the rate, at which the material is removed from the sample during the bombardment by energetic ions. The sputter yield $(Y)$ is derived from the density and energy of

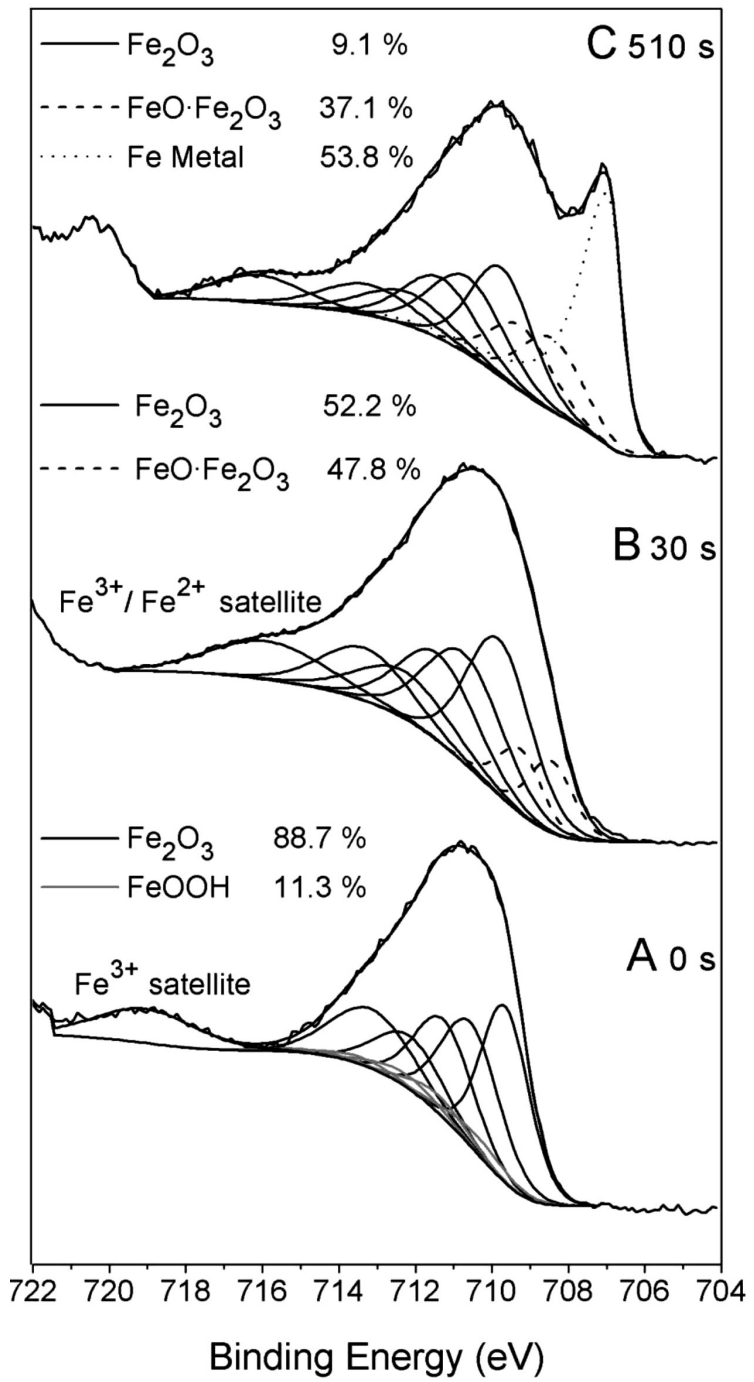

Figure 3: Corrosion-product components at various depths for the sample heated at $600{ }^{\circ} \mathrm{C}$ for $24 \mathrm{~h}$

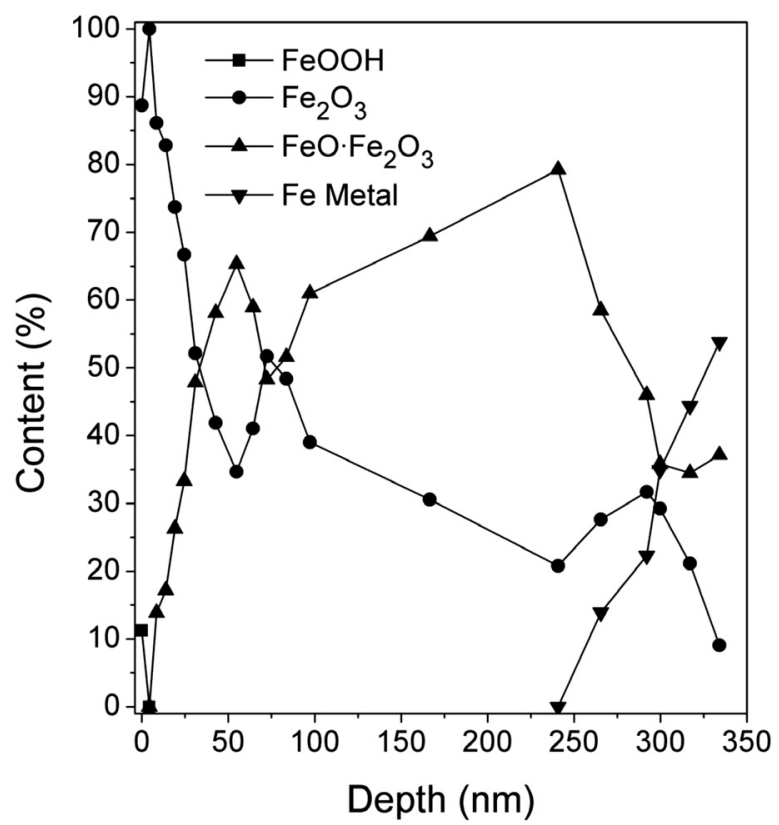

Figure 4: Character of the corrosion layer of the sample heated at $600{ }^{\circ} \mathrm{C}$ for $24 \mathrm{~h}$

sublimation of the specific chemical compound. ${ }^{7}$ Subsequently, after substituting it into the equation, the etch rate $R$ is defined: ${ }^{8}$

$$
R=\frac{10^{-2} I Y w}{\rho A}\left(\mathrm{~nm} \mathrm{~s}^{-1}\right)
$$

where $I=$ ion-beam current $(\mu \mathrm{A}), w=$ molar weight $\left(\mathrm{g} \mathrm{mol}^{-1}\right), \rho=$ density $\left(\mathrm{g} \mathrm{cm}^{-3}\right)$ and $A=$ raster area $\left(\mathrm{mm}^{2}\right)$. The depth of the etched layer in the specific time of ion sputtering is related to the proportions of individual phases; therefore, the XPS quantification analysis becomes an inseparable part of depth profiling. If the percent proportion of a particular phase is related to coefficient $k$, the etch rate $R$ and the time of etching $t$, then the etched multi-compound layer thickness $T$ is given by:

$$
T=\left(k_{1} \cdot R_{1}+k_{2} \cdot R_{2}+k_{n} \cdot R_{n}\right) t(\mathrm{~nm})
$$

Thanks to the sequential ion etching and depth profile analysis, the character of the corrosion layer is shown in Figure 4.

\section{CONCLUSIONS}

This paper demonstrates a fast and easy method for the characterization of the corrosion layer on steel samples. Through both the sequential destructive method of ion etching and a detailed XPS analysis, it is possible to identify the exact amount of each corrosive product at a given depth. Based on the chemical composition and ion-gun setting, the degree and speed of ion etching were calculated. Based on the amount of each corrosion prod- 


\section{KALINA et al.: THICKNESS DETERMINATION OF CORROSION LAYERS ON IRON USING XPS DEPTH PROFILING}

uct and its etch rate, the character of the corrosion layer in a specific corrosion environment was derived.

\section{Acknowledgement}

This outcome was achieved with the financial support for the project: Materials Research Centre at FCH BUT Sustainability and Development, REG LO1211, the financial support from the National Programme for Sustainability I (Ministry of Education, Youth and Sports).

\section{REFERENCES}

A. Einstein, Concerning an heuristic point of view towards the emission and transformation of light, Annalen der Physik, 17 (1905), $132-148$
${ }^{2}$ C. S. Fadley, X-ray photoelectron spectroscopy: Progress and perspectives, Journal of Electron Spectroscopy and Related Phenomena, 41 (2010), 178-179, doi:10.1016/j.elspec.2010.01.006

${ }^{3}$ O. Renault, High-resolution XPS spectromicroscopy, Surface and Interface Analysis, 42 (2010), 816-825, doi:10.1002/sia.3521

${ }^{4}$ R. Steinberger, J. Walter, T. Greunz, J. Duchoslav, M. Arndt, S. Molodtsov, D. C. Meyer, D. Stifter, XPS study of the effects of long-term $\mathrm{Ar}^{+}$ion and $\mathrm{Ar}$ cluster sputtering on the chemical degradation of hydrozincite and iron oxide, Corrosion Science, 99 (2015), 66-75, doi:10.1016/j.corsci.2015.06.019

${ }^{5}$ R. P. Gupta, S. K. Sen, Calculation of multiplet structure of core p-vacancy levels, Physical Review B, 10 (1974), 71-77, doi:10.1103/PhysRevB.10.71

${ }^{6}$ R. P. Gupta, S. K. Sen, Calculation of multiplet structure of core p-vacancy levels II, Physical Review B, 12 (1975), 15-19, doi:10.1103/PhysRevB.12.15

${ }^{7}$ M. P. Seah, T. S. Nunney, Sputtering yields of compounds using argon ions, Journal of Physics D, 43 (2010), 1-13, doi:10.1088/ 0022-3727/43/25/253001

${ }^{8}$ J. F. Watts, J. Wolstenholme, An introduction to surface analysis by XPS and AES, $2^{\text {nd }}$ ed., Wiley, Chichester 2003, 226 